\title{
“清水白桃”樹の窒素およびカリウム栄養状態と果実糖度との関係
}

\author{
高野和夫 ${ }^{1 *} \cdot$ 木村 $\quad$ 剛 ${ }^{1 a} \cdot$ 山本章吾 ${ }^{1} \cdot$ 森次真一 ${ }^{1} \cdot$ 岡本五郎 ${ }^{2}$ \\ 1 岡山県農業総合センター農業試験場７09-0801＼cjkstart赤磐市神田沖 \\ 2 岡山大学大学院自然科学研究科 700-8530 岡山市津島中
}

\section{Relationship between Fruit Total Soluble Solid Contents and Tree Nitrogen and Potassium Contents in 'Shimizu-Hakuto' Peach}

\author{
Kazuo Takano ${ }^{1 *}$, Tsuyoshi Kimura ${ }^{1 a}$, Shogo Yamamoto ${ }^{1}$, Shinichi Moritsugu ${ }^{1}$ and Goro Okamoto ${ }^{2}$ \\ ${ }^{1}$ Agricultural Experiment Station, Okayama Prefectural General Agriculture Center, Akaiwa, Okayama 709-0801 \\ ${ }^{2}$ Graduate School of Natural Science and Technology, Okayama University, Okayama 700-8530
}

\begin{abstract}
Total soluble solid contents in fruit (fruit TSS), and nitrogen (N) and potassium (K) contents in leaf and fruit of 'Shimizuhakuto' peach were analyzed in 23 orchards located in the south part of Okayama Prefecture during the seasons from 1997 to 1999. Significant negative correlations were obtained between fruit TSS and N contents in leaf, K contents in leaf, and N contents in fruit juice, where the correlation coefficients were $-0.477,-0.677$, and -0.616 , respectively. The correlation coefficient between fruit TSS and leaf N contents was highest at 60 days after full bloom, and then decreased with the progression of growth season. On the other hand, the variation of correlation coefficients between fruit TSS and leaf K contents among growth seasons was small. The analysis of the relationship between annual changes of fruit TSS and nutritional status of peach trees revealed that fruit TSS increased in the trees where leaf or fruit juice $\mathrm{N}$ contents decreased than those in previous year.
\end{abstract}

Key Words : diagnosis of nutrient condition, fruit quality, leaf analysis

キーワード：栄養診断，果実品質，葉分析

\section{緒言}

光センサーによるモモの非破壊糖度選果を行っている産 地に颃いては，糖度の違いにより販売価格に差が生じるた め, 外観品質の向上に加えて内部品質の一つである糖度の 高い果実を生産することが，収益向上のための必須条件と なった. 岡山県南部の選果場に拈いて, “清水白桃’の糖度 と気象条件との関係を解析すると, 糖度は日照時間が多く 雨量が少ない年ほど高く, 1993 年以降の 6 年間に扮ける糖 度の最高年と最低年との差は $2.6^{\circ}$ Brix であった. 一方，生 産者別に糖度を比較すると, 天候不順な年でも糖度の高い 果実生産者が存在する反面, 天候が良好な年でも糖度の低 い果実生産者が存在し，同一年次に打ける糖度の生産者間 差は最大で約 $4.5^{\circ}$ Brix であり, 気象要因以上に栽培環境要 因による影響の方が大きいことが明らかになった（岡山県 農業総合センター, 2003). そこで, 筆者らは糖度の高いモ モの安定生産技術を確立するために, 岡山県南部における

2006 年 8 月 13 日 受付. 2007 年 4 月 3 日 受理.

* Corresponding author. E-mail: kazuo_takano@pref.okayama.lg.jp

a 現在 : 井笠農業普及指導センター
“清水白桃’園の中で, 糖度の高い果実を生産する園地と低 い果実を生産する園地の樹の生育状態, 栄養状態並びに土 壤状態を比較調査した。 その結果，糖度は樹冠下の相対照 度（岡山県農業総合センター，2003）や土塞中の全窒素含 量（山本，2002）などと相関が高いことが明らかになった。 本報告は，その中で糖度に最も大きな影響を及ぼすと推察 された, 樹体の窒素（N）㧊よびカリウム（K）栄養状態と 果実中糖度との関係について報告するものである.

\section{材料および方法}

\section{1. 現地調查 \\ 1) 単年度調査}

岡山県南部の丘陵地から水田転作地までの地域に招い て, 1997 年は 13 園, 1998 年は前年の 13 園のらちの 10 園 に新たに 10 園を加えた 20 園に栽植された ‘清水白桃”の それぞれ 13 樹と 27 樹について, 生育状態を調査するとと もに葉拈よび収穫果実（有袋栽培）の成分分析を行った. 調査樹の樹齢は $6 \sim 15$ 年生で, 園地により剪定強度並びに 着果量はやや異なった。 調査樹の 1997 年抢よび 1998 年の 満開日はそれぞれ 4 月 $6 \sim 9$ 日と 4 月 $5 \sim 8$ 日, 収穫日は それぞれ7月 $25 \sim 31$ 日と 7 月 $13 \sim 30$ 日であった. 


\section{2) 年次変動調査}

1997 年並びに 1998 年の調査園では, 調査結果を生産者に 随時報告し, $\mathrm{N}$ や $\mathrm{K}$ が過剰で糖度が低いと診断される園地 には，肥料，堆肥，敷きわら並びに敷き草の過㮃施用の是 正を促した，その中の 13 園 17 樹については，1999年も継 続して葉执よび果実の成分分析を行い，同一園地に拈ける 樹体栄養状態の年次变化が糖度に及ぼす影響を解析した。

\section{2. 葉分析}

満開後約 30，60，90，120 および 150 日に，結果枝先端 の新梢長が平均的な枝について，基部のごく小さな 1,2 枚 の葉を除いて, 葉身の長さが $5 \mathrm{~cm}$ 以上の葉から先端側に 3 枚目 (30 日後), $6 \sim 10$ 枚目 (60日後以降) の葉を 1 樹当 たり $15 \sim 20$ 枚採取した. 水洗後に $70^{\circ} \mathrm{C} て ゙$ 通風乾燥し, 粉 砕機（サイクロンサンプルミル，UDY）で粉砕した. この 粉末試料について, 高野ら（1998）の方法に準じて近赤外 分光光度計（6500 型， NIRSystems）を用いて $\mathrm{N}$ および $\mathrm{K}$ 含量を測定した。

\section{3. 果実分析}

果頂部から果実赤道部まで緑色が消失し, 梗あ部に緑色 が残る果実を，1樹当たり $10 \sim 30$ 個採取した。糖度の測 定には果実赤道部のほ打の部分の果肉を果皮面から深さ 2 〜 $3 \mathrm{~cm}$ に至るまでクサビ状に切り取り, 手で搾汁して屈折 計（No. 95973, PIKA）で測定した. また，1樹当たり 5〜 10 果から, 果実のほ打の部分の果肉を果皮面から核に至る までクサビ状に切り取り, ビニル袋内で潰して得た果汁を 紙ワイパー（キムワイプ，クレシア）でろ過した. この果 汁について, $0.02 \mathrm{M}$ 水酸化ナトリウム液を用いた中和滴定 法により酸含量を, また, 果汁 $10 \mathrm{~mL}$ に硫酸 $5 \mathrm{~mL}$ と過酸 化水素 $(2 \mathrm{~mL} \times 5$ 回）を加えて加熱分解した後, 七ミミク ロ蒸留法により全 $\mathrm{N}$ 含量を測定した.

\section{4. 生育調査}

満開後 90 日に, 側枝単位で全葉芽数に対する伸長中の新 梢数の割合（伸長新梢率）を調査した．落葉後（11月中旬） には, 側枝単位で全新梢を花束状短果枝 $(2 \mathrm{~cm}$ 未満), 短 果枝 $(2 \sim 10 \mathrm{~cm})$, 中果枝 $(10 \sim 30 \mathrm{~cm})$, 長果枝 (30〜 $60 \mathrm{~cm}$ )，徒長枝（60 cm 以上）に区分し，それぞれ全新梢 数に対する比率を算出した。 また, 満開後 120 日には, 樹 冠下の照度を照度計（LX-1332, カスタム）で測定し，樹 冠外の照度に対する相対值を算出した。

\section{結 果 \\ 1. 葉中 $N$ および $\mathrm{K}$ 含量と糖度との関係}

収穫果実の糖度（Brix）と葉中 $\mathrm{N}$ 含量との間に，1997年 並びに 1998 年とも，負の相関が認められた（第 1 表，第 1 図). 糖度と葉中 $\mathrm{N}$ 含量との相関を生育時期別にみると, 両 年ともに生育初期の満開後 $30 \sim 60$ 日の相関係数 (r) の值 が最も高く有意で，90日，120日と生育時期が進むにつれ 低下する傾向にあった. 葉中 $\mathrm{K}$ 含量にも両年ともに糖度と の間に負の相関が認められ（第 1 表，第 1 図)，その $\mathrm{r}$ 值は 1998 年ではいずれの生育時期に扎いても葉中 $\mathrm{N}$ 含量との $\mathrm{r}$ 值よりも高かった. 糖度と葉中 $\mathrm{K}$ 含量との相関を生育時期 別にみると, $\mathrm{K}$ 含量は $\mathrm{N}$ 含量に比べ満開後 $60 \sim 150$ 日の $\mathrm{r}$ 值の変動は小さかった。 な打, 満開後 60 日の葉中の $\mathrm{N}$ 含 量と $\mathrm{K}$ 含量とは正の相関関係 $(r=0.730,0.1 \%$ 水準で有意, 1998 年) にあった.

1998 年に調査した 27 樹の葉中 $\mathrm{N}$ および $\mathrm{K}$ 含量の経時変 化を第 2 図に示した.なお， 27 樹について，糖度（Brix） が $13.0^{\circ}$ 以上, $12.0 \sim 12.9^{\circ}, 11.0 \sim 11.9^{\circ}$ および $11.0^{\circ}$ 未満 の果実を生産する樹をそれぞれ太実線, 細実線, 極細実線 扣よび太点線で示した，葉中 $\mathrm{N}$ 含量は生育時期が進むにつ れて減少したが，その速度には樹間差があり，満開後 60 120 日にかけて急激に減少する樹と緩やかに減少する樹が 存在した. 満開後 60 日の葉中 $\mathrm{N}$ 含量が多くても，その後 の減少が大きい樹では比較的糖度が高かった. 葉中 $\mathrm{K}$ 含量 も生育時期が進むにつれ徐々に減少する傾向にあったが, 満開後 $60 \sim 150$ 日にかけてほとんど減少しない樹や, 満開 後 $90 \sim 120$ 日にかけて大きく減少する樹が存在した.

\section{2. 果汁中 $\mathrm{N}$ 含量と糖度との関係}

果汁中 N 含量が多い果実汪ど糖度が低い傾向が 1997 年 $(\mathrm{r}=-0.752,1 \%$ 水準で有意）拈よび 1998 年 $(\mathrm{r}=-0.616$, $0.1 \%$ 水準で有意，第 1 図）ともに認められ，その $\mathrm{r}$ 值は 1998 年では満開後 60 日に打ける葉中 $\mathrm{N}$ 含量との $\mathrm{r}$ 值より も高く, 満開後 $60 \sim 90$ 日に打壮る葉中 $\mathrm{K}$ 含量との $\mathrm{r}$ 值と 同程度であった。

1998 年の調査では，果汁中 $\mathrm{N}$ 含量と満開後 60 日におけ る葉中 $\mathrm{N}$ 含量並びに満開後 $60 \sim 150$ 日に打ける葉中 $\mathrm{K}$ 含 量とは有意な正の相関関係（それぞれ $\mathrm{r}=0.438, \quad \mathrm{r}=0.657$ 〜 0.552) にあった。果汁中 $\mathrm{N}$ 含量と葉中 $\mathrm{K}$ 含量との相関

第 1 表 “清水白桃’ 樹の生育時期別葉中 $\mathrm{N}$ および $\mathrm{K}$ 含量と収穫果実の糖度との相関係数 $\mathrm{z}$

\begin{tabular}{|c|c|c|c|c|c|c|c|}
\hline \multirow{2}{*}{ 葉中成分 } & \multirow{2}{*}{ 調査年 } & \multirow{2}{*}{ 調査樹数 } & \multicolumn{5}{|c|}{ 葉中成分含量と糖度との相関係数 } \\
\hline & & & 満開後 30 日 & 60 日 & 90 日 & 120 日 & 150 日 \\
\hline \multirow[t]{2}{*}{$\mathrm{N}$} & 1997 年 & 13 & $-0.82 * * *$ & $-0.80 * *$ & $-0.74 * *$ & $-0.68^{*}$ & -0.46 \\
\hline & 1998 年 & 27 & $-^{\mathrm{y}}$ & $-0.48^{*}$ & $-0.39 *$ & -0.23 & $-0.44 *$ \\
\hline \multirow[t]{2}{*}{$\mathrm{K}$} & 1997 年 & 13 & -0.35 & $-0.66^{*}$ & $-0.60^{*}$ & $-0.68 *$ & -0.52 \\
\hline & 1998 年 & 27 & $-^{\mathrm{y}}$ & $-0.68 * * *$ & $-0.61 * * *$ & $-0.51 * *$ & $-0.61 * * *$ \\
\hline
\end{tabular}

${ }^{\mathrm{z}}$ 相関係数の有意水準: $* 5 \%, * * 1 \%, * * * 0.1 \%$, 糖度 ( ${ }^{\circ}$ Brix) の (最低值〜最高值) $: 1997$ 年 $(11.8 \sim 13.4), 1998$ 年 $(9.9 \sim 13.8)$ ${ }^{\mathrm{y}}$ 未調查 

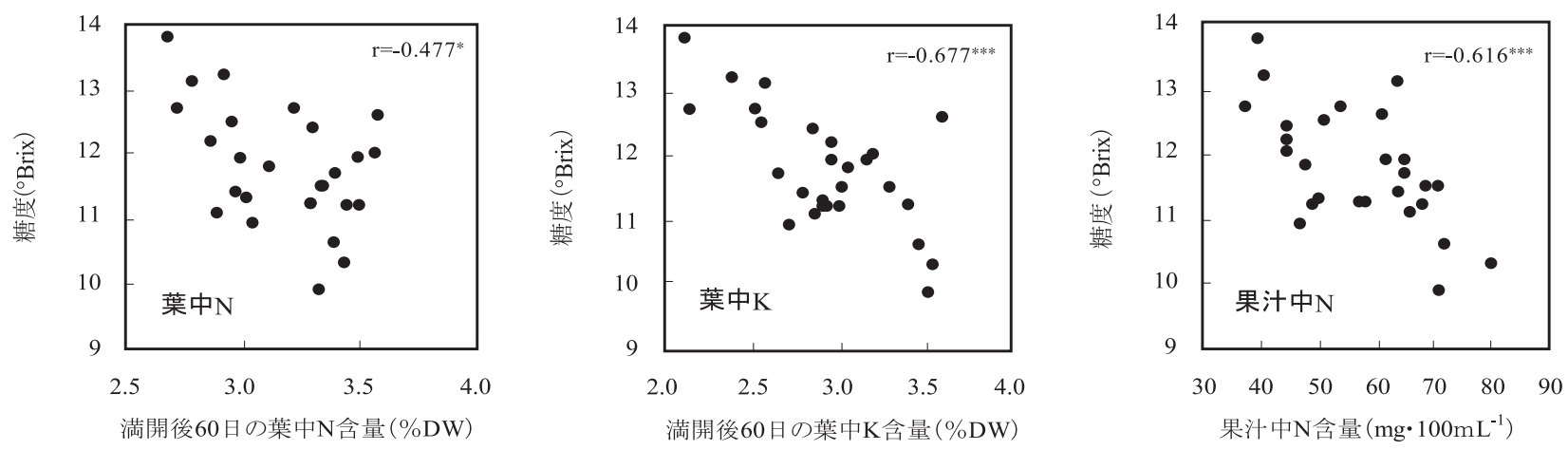

第 1 図“清水白桃’樹に抢ける収穫果実の糖度と葉中 $\mathrm{N}$ 抢よび $\mathrm{K}$ 含量並びに果汁中 $\mathrm{N}$ 含量との関係（1998 年，有意水準：* $5 \%$, $* * 1 \%, * * * 0.1 \%, \mathrm{n}=27$ 樹)
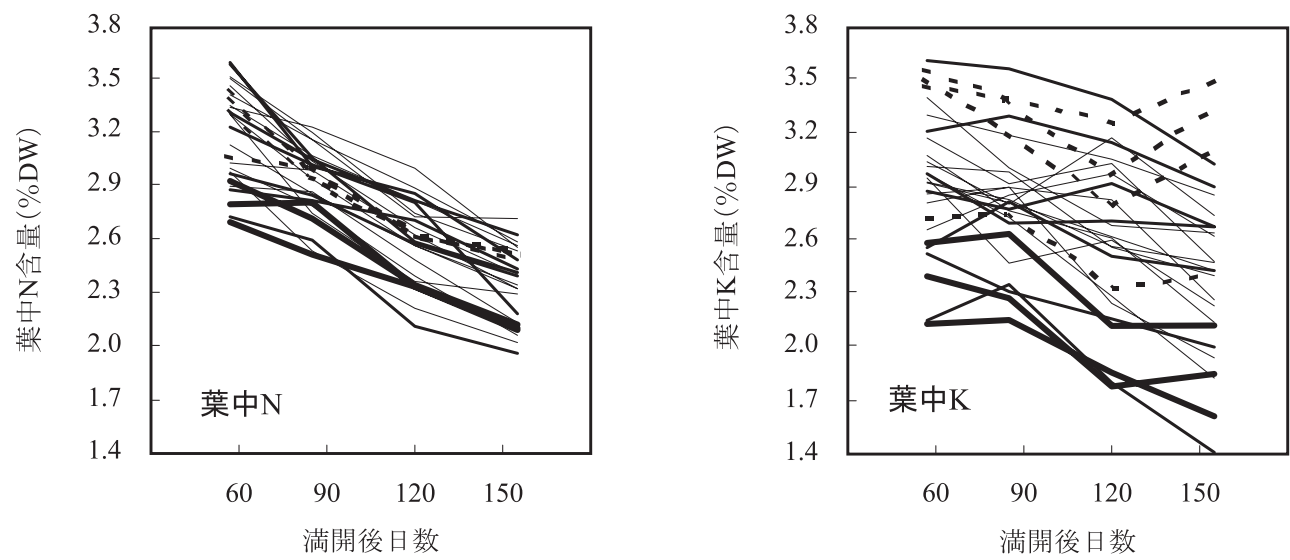

太実線：13.0 ${ }^{\circ}$ Brix以上 細実線 : $12.0 \sim 12.9^{\circ}$ Brix 極細実線：11.0 $11.9^{\circ}$ Brix 太点線 : $11.0^{\circ}$ Brix未満 の果実生産樹

第 2 図 “清水白桃’ 27 樹の葉中 $\mathrm{N}$ 打よび $\mathrm{K}$ 含量の経時变化（1998 年）

を，両者の $\mathrm{r}$ 值が最も高かった満開後 60 日に掞いて，糖度 （Brix）との関連をみるために糖度が 12.0 以上の果実を生 産する樹とそれ以下の樹に区分して第 3 図に示したが, 葉 中 $\mathrm{K}$ 含量が $2.6 \%$ 未満であるか, 果汁中 $\mathrm{N}$ 含量が $47 \mathrm{mg}$ $100 \mathrm{~mL}^{-1}$ 未満である樹では, 糖度がすべて $12.0^{\circ}$ 以上であ り, 逆に，葉中 $\mathrm{K}$ 含量が $2.6 \%$ 以上かつ果汁中 $\mathrm{N}$ 含量が $47 \mathrm{mg} \cdot 100 \mathrm{~mL}^{-1}$ 以上の樹では, 1 樹を除いたすべての樹に 扮いて糖度が $12.0^{\circ}$ 未満であった。 また, 酸含量と糖度と の間に負の相関 $(\mathrm{r}=-0.554,1 \%$ 水準で有意 $)$ が認められ, 酸含量と果汁中 $\mathrm{N}$ 含量との間には正の相関 $(\mathrm{r}=0.522,1 \%$ 水準で有意）が認められたが，果実重と糖度との間に有意 な相関 $(r=0.029)$ は認められなかった.

\section{3. 樹体栄養状態の年次変動と糖度との関係}

継続調査樹の中には, 前年よりも糖度が上昇した樹と低 下した樹が存在した。 この糖度の年次変動と樹の栄養状態 との関係を 1998 年と 1999 年とで比較すると, 満開後 90 日 の葉中 $\mathrm{N}$ 含量が前年より減少した樹活ど糖度が前年よりも 上昇する傾向が認められた（第 4 図）。 また，果汁中 $\mathrm{N}$ 含 量でも同様な傾向が認められ, 調查樹別の果汁中 $\mathrm{N}$ 含量の 年次間差と糖度の年次間差とは負の相関 $(\mathrm{r}=-0.619, \quad 1 \%$ 水準で有意）を示した. なお, 満開後 60 日の葉中 $\mathrm{K}$ 含量 の年次間差と糖度の年次間差との $\mathrm{r}$ 值は -0.471 であった。

\section{4. 樹の栄養状態と生育状態との関係}

1998 年の調査では, 満開後 $60 \sim 90$ 日の葉中 $\mathrm{N}$ 含量が多 い樹䚾ど満開後 90 日の伸長新梢率が高く, 11 月中旬の長 果枝拈よび徒長枝割合が増加し, 満開後 120 日の樹冠下の 相対照度が低い傾向にあった (第 2 表).これらの生育状態 と葉中 $\mathrm{N}$ 含量との相関において $\mathrm{r}$ 值は満開後 60 日が最も 高く, その後は生育時期が進むにつれて低下した．葉中 $\mathrm{K}$ 含量も葉中 $\mathrm{N}$ 含量と同じ傾向を示したが, 葉中 $\mathrm{K}$ 含量と伸 長新梢率並びに長果枝および徒長枝割合との相関におい て, $\mathrm{r}$ 值が最も高かったのは満開後 90 日であった。また, 果汁中 $\mathrm{N}$ 含量も長果枝扎よび徒長枝割合と正の相関を示し たが，その $\mathrm{r}$ 值は満開後 60 日の葉中 $\mathrm{N}$ 含量および満開後 $60 \sim 90$ 日の葉中 $\mathrm{K}$ 含量との $\mathrm{r}$ 值よりも低かった. そして, 徒長枝の発生が多く満開後 120 日の樹冠下の相対照度が低 い樹ほど糖度が低い傾向にあった。

\section{考察}

肥料や堆肥を過唾に施用したモモ樹では, 収穫果実の糖 度が低い傾向にあることが報告されている(小池，1992; 繁 田ら，1991; 渡辺，1960）。 また，モモ樹の栄養状態に関し て, 樹体内の $\mathrm{N} や \mathrm{~K}$ の過剰な状態が果実への糖の蓄積を抑 制することも報告されている（村田，1979; 岡本ら，1989）. 


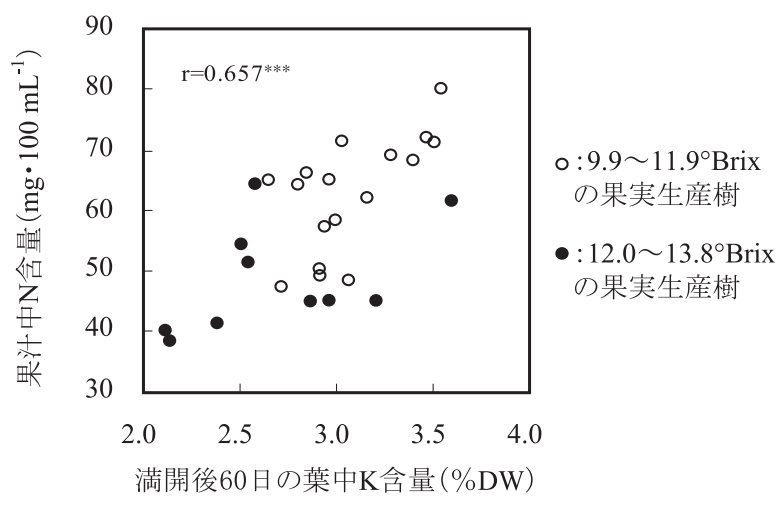

第 3 図“清水白桃”樹の葉中 $\mathrm{K}$ 含量と収穫果実果汁中 $\mathrm{N}$ 含量 との関係（1998 年，有意水準：***0.1\%, $\mathrm{n}=27$ 樹）

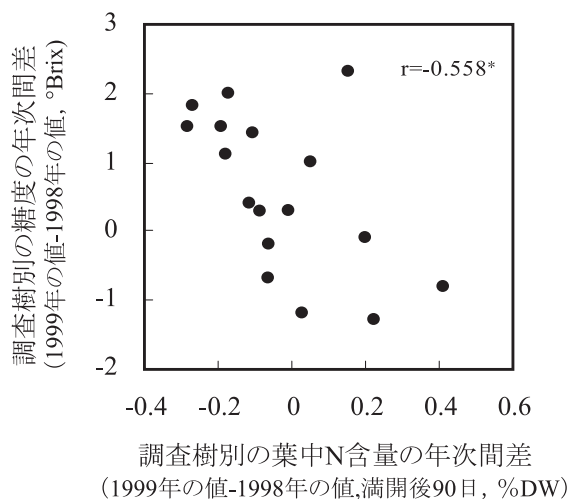

第 4 図“清水白桃’調査樹別の 1998 年に対する 1999 年の葉 中 $\mathrm{N}$ 含量の年次間差と収穫果実の糖度の年次間差との 関係（有意水準 : * 5\%, $\mathrm{n}=17$ 樹）

第 2 表 “清水白桃” 樹の栄養状態と生育状態との相関係数 ${ }^{\mathrm{z}}$

\begin{tabular}{|c|c|c|c|c|c|c|c|c|c|c|}
\hline \multirow{2}{*}{ 生育状態 } & \multirow{2}{*}{ （生育時期） } & \multirow{2}{*}{ 糖度 } & \multirow{2}{*}{$\begin{array}{l}\text { 果汁中 } \\
\mathrm{N} \text { 含量 }\end{array}$} & \multicolumn{3}{|c|}{ 葉中 N 含量 } & \multicolumn{3}{|c|}{ 葉中 K 含量 } & \multirow{2}{*}{$\begin{array}{l}\text { 樹冠下の } \\
\text { 相対照度 }\end{array}$} \\
\hline & & & & 満開後 60 日 & 90 日 & 120 日 & 満開後 60 日 & 90 日 & 120 日 & \\
\hline 相対照度 & (満開後 120 日) & $0.62 * * *$ & $-0.56 * *$ & $-0.46^{*}$ & -0.25 & -0.15 & $-0.70 * * *$ & $-0.60 * * *$ & -0.37 & 1 \\
\hline 伸長新梢率 & （満開後 90 日） & -0.27 & 0.23 & $0.67 * * *$ & $0.54 * *$ & $0.40^{*}$ & $0.46^{*}$ & $0.64 * * *$ & $0.61 * * *$ & -0.37 \\
\hline 長果枝割合 & （11 月中旬） & -0.36 & $0.48^{*}$ & $0.56^{* *}$ & $0.41^{*}$ & 0.33 & $0.59 * *$ & $0.73 * * *$ & $0.49 * *$ & $-0.55 * *$ \\
\hline 徒長枝割合 & （11 月中旬） & $-0.55 * *$ & $0.42 *$ & $0.60 * * *$ & $0.45^{*}$ & 0.30 & $0.54 * *$ & $0.58 * *$ & $0.42 *$ & $-0.58 * *$ \\
\hline
\end{tabular}

${ }^{\mathrm{z}} 1998$ 年，相関係数の有意水準 : * 5\%, ** $1 \%, * * * 0.1 \%, \mathrm{n}=27$ 樹

さらに, $\mathrm{N}$ 過多は糖含量以外に肉質や香り，らまみ, 日持 ちにも影響し，モモの総合的な食味を大きく左右する（Jia ら, 1999, 2000; 岡本, 2001; Okamoto ら, 2001; 高野ら, 2004).

“清水白桃”に打ける本調査でも, 葉中や果汁中の $\mathrm{N}$ 含 量が多いと糖度が低い傾向が認められた。 $\mathrm{N}$ 過多になる原 因には，肥料や堆肥，敷きわらなどの過㮃施用があげられ るが, 特に有機物の過剰連用により土壤中の全 $\mathrm{N}$ および腐 植含量が増加した園地では, 夏期に土壌中の無機態 $\mathrm{N}$ が増 加し，糖度が低くなる傾向にある（山本，2002），そして, $\mathrm{N}$ 過多による糖度低下の原因には，新梢の遅伸びや再伸長 による光合成産物である糖の果実への分配率低下や，徒長 枝の多発による結果枝の日照不良，果実肥大の促進による 糖の希釈効果などがあげられる.

モモ樹の $\mathrm{N}$ 栄養と糖度との関係を考える上では, 生育時 期別の栄養状態の影響も考慮する必要がある. 本調査では, 第 2 図に示したように葉中 $\mathrm{N}$ 含量が果実成熟期にかけて大 きく減少する樹と緩やかに減少する樹が存在した. これは, 園地により夏期の土潩からの $\mathrm{N}$ 無機化量が異なることや, 土壤の水分条件により細根の吸収活性が異なるため, 果実 成熟期に N 吸収量の少ない樹では，葉から果実などへの N の移行が進むためと推察された。岡本ら（1989）はモモ樹 を種々の濃度の組合せで養液栽培し, 生育初期の施肥量が 多過ぎると糖度が低いことと, 硬核期以降に施肥量を早く 減量した区臣糖度が高いことを報告している，本調査で も果実成熟期の葉中 $\mathrm{N}$ 含量の減少パターンにより糖度に差 が認められたことから, 収穫時の糖度には生育初期の $\mathrm{N}$ と
果実成熟期の $\mathrm{N}$ が相互に影響するものと推察された. 従っ て, 葉中 $\mathrm{N}$ 含量で樹体の $\mathrm{N}$ 栄養状態を診断する場合は, 生 育初期の $\mathrm{N}$ 含量とともに，その後の減少パターンも考慮す る必要があると考光られた。

村田（1979）は収穫果実の果肉中の N 含量と糖度との間 に極めて高い負の相関を認めている．本調査では，分析作 業の省力化を図るために簡便に調整できる果汁を $\mathrm{N}$ 分析に 供したが，果汁中 $\mathrm{N}$ 含量と糖度との間にも負の相関が認め られ，その $\mathrm{r}$ 值は葉中 $\mathrm{N}$ 含量と糖度との $\mathrm{r}$ 值よりも高かっ た．今後，果実中の $\mathrm{N}$ 含量が糖集積に及ぼす影響について 検討が必要と考える.

“清水白桃” の葉中 $\mathrm{K}$ 含量と糖度とは負の相関を示した. $\mathrm{K}$ とモモ果実中の糖含量との関係について, Cummings・ Reeves (1971) や福田・近藤（1957）は K 施用量の増加に より糖含量が低下することを認め，村田（1979）は収穫時 の果肉中 $\mathrm{K}$ 含量と糖度との間に負の相関があることを認め ている，モモ以外では，ナシ（佐藤ら，1995）やオウトウ （須藤ら，1995）でも葉中 $\mathrm{K}$ 含量と糖度との間に負の相関 が認められている，Kはデンプンなどの多糖類やタンパク 質の合成を促進し（大平，1969），N とともに樹体の成長や 果実肥大を促進する。従って，Kの過㮃は過度の新梢成長 と果実肥大を招き，果実への糖集積を抑制するものと考兄 られた。

$\mathrm{N}$ と K の相互関係について, オウトウでは $\mathrm{N}$ 施用量が少 ない場合は K 施用量の増加により糖度が低下寸るのに対 し， N 施用量が多い場合は $\mathrm{K}$ 施用量の多少に関わらず糖度 
が低いことが認められている(須藤，1993）。“清水白桃’に おける本調査では，葉中の $\mathrm{N}$ 含量と $\mathrm{K}$ 含量との相関が高 く, 糖度に対する $\mathrm{N}$ と $\mathrm{K}$ の影響を分けて判断することは難 しいが, 第 3 図に示した糖度別の果汁中 $\mathrm{N}$ 含量と葉中 $\mathrm{K}$ 含 量との関係から，モモでも糖度に対して $\mathrm{N}$ と K が相互に影 響するものと考えられた。

樹別の糖度の年次変動解析から, 糖度は樹体の $\mathrm{N}$ 栄養状 態の変動に敏感に反応することが推察された．糖度の低い 果実を生産する園地の改善に当たっては，糖度が低い原因 が栄養過多にあるのか，その他の栽培環境要因にあるのか を明確にし，栄養過多であれば，生育初期の $\mathrm{N}$ 過多が原因 なのか，果実成熟期の $\mathrm{N}$ 過多が原因なのか，あるいは $\mathrm{K}$ 過 多が原因なのかを判断し，その改善に取り組むことにより 糖度の向上を図ることが可能であると考える，一方，糖度 の高い果実を生産する園地では，樹勢の低下を招くことの ないよう適切な施肥や土壌改良を継続し, 適正な樹体栄養 状態を保つことにより，食味が優れる果実を毎年生産する ことが可能になると考える.

\section{摘 要}

1997 ～ 1999 年に，岡山県南部に抋いて“清水白桃’を 栽培する 23 園で, 収穫果実の糖度とそれを生産した樹の葉 中 $\mathrm{N}$ および $\mathrm{K}$ 含量並びに果汁中 $\mathrm{N}$ 含量との関連を調査し た。糖度と葉中 $\mathrm{N}$ および $\mathrm{K}$ 含量並びに果汁中 $\mathrm{N}$ 含量との 間にはそれぞれ有意な負の相関が認められ，その相関係数 はそれぞれ $-0.477 ，-0.677 ，-0.616$ であった。糖度と葉中 $\mathrm{N}$ 含量との相関係数は満開後 60 日が最も高く, 生育時期が 進むにつれて低下した，一方，糖度と葉中 $\mathrm{K}$ 含量との相関 係数は生育時期による変動が小さかった。 また，モモ樹の 栄養状態の年次変動と糖度の年次変動との関係を解析した 結果, 当年の葉中 $\mathrm{N}$ 含量や果汁中 $\mathrm{N}$ 含量が前年よりも減少 した樹ほど糖度が上昇する傾向が認められた。

謝 辞 現地調查に打いて御協力と御助言を頂いた生産 者の方々に厚く御礼申乙上げます。現地調査は JA，農業改 良普及七ンタ一，農業総合センタ一総合調整部並びに農業 試験場により合同で行ったことを明記し，調査に御協力頂 いた職員各位に感謝の意を表します。特に，調査園地の選 定と現地調查に多大の御協力と御指導を頂いた JA 営農指 導員の故 三宅 明氏に深く感謝いたします。 また，本稿 の執筆に当たり御指導頂いた前岡山大学農学部教授多田幹 郎博士に深謝いたします。

\section{引用文献}

Cummings, G. A. and J. Reeves. 1971. Factors influencing chemical characteristics of peaches. J. Amer. Soc. Hort. Sci. 96: $320-322$.

福田 照・近藤権一. 1957. 桃樹の栄養に関する研究（第
4 報）結果樹に及ぼす 3 要素施用濃度及び比率の影響. 京都大園芸学集録. 8: 16-23.

Jia, H., K. Hirano and G. Okamoto. 1999. Effects of fertilizer levels on tree growth and fruit quality of 'Hakuho' peaches (Prunus persica). J. Japan. Soc. Hort. Sci. 68: 487-493.

Jia, H., G. Okamoto and K. Hirano. 2000. Effect of amino acid composition on the taste of 'Hakuho' peaches (Prunus persica Batsch) grown under different fertilizer levels. J. Japan. Soc. Hort. Sci. 69: 135-140.

小池 明. 1992. 堆肥の施用が新規開園土壌の理化学性並 びにモモ樹の生育と果実品質に及ぼす影響。徳島果試 研報. 20: 11-22.

村田隆一. 1979. モ乇の施肥と品質に関する研究. 滋賀農 試特研報。12: 1-95.

岡本五郎. 2001. モモの味・香りを低下させる過剰施肥. 農及園. 76: 349-354.

岡本五郎・藤井雄一郎・島村和夫. 1989. ユスラウメ台モ モ樹の生育と果実品質に及ぼす培養液濃度の影響. 生 物環境調節. 27: 83-87.

Okamoto, G., H. Jia, A. Kitamura and K. Hirano. 2001. Effect of different fertilizer application levels on texture of 'Hakuho' peach (Prunus persica Batsch). J. Japan. Soc. Hort. Sci. 70: 533-538.

岡山県農業総合センター編. 2003. 糖度の高いモモ生産の ための栽培管理指標. p. 1-62. 岡山県農業総合セン ター。岡山.

大平幸次. 1969．必須元素．p. 59-80．高橋英一編著．作物 栄養学. 朝倉書店. 東京.

佐藤康一・斎藤 隆・中西政則・平沢秀弥． 1995. 山形県 に抢ける日本ナシ園の土㙥特性と果実品質. 東北農研. 48: 181-182.

繁田充保・海野孝章・依田征四１1991．モモの果実品質に 関する研究（第 2 報）栽培条件の相違が果実肥大及び 品質（糖，酸）に及ぼす影響．岡山農試研報．9：69-74 須藤佐蔵. 1993. 農業技術体系果樹編 4. オウトウ基本技 術編. p. 47-51. 農文協. 東京.

須藤佐蔵・山口金栄・梅津英樹．1995．オウトウ ‘佐藤錦” の生育診断技術に関寸る研究. 山形園試研報. 11: 1-16. 高野和夫・森次真一・山本章吾. 2004. モモの樹の栄養状 態と果実の日持ち性との関係. 園学雑. 73 (別 2) : 539 . 高野和夫・妹尾知憲・村西久美・海野孝章. 1998．近赤外 分光法によるモモ葉中無機成分の迅速測定. 近畿中国 農研. 96: 26-30

渡辺照夫. 1960. 桃の施肥法. 農及園. 35: 1909-1912.

山本章吾. 2002. 高糖度乇モ生産と土壤要因. 農耕と園芸. 57: 176-179. 